\title{
Physiological quality of physic nut (Jatropha curcas L.) seeds during storage ${ }^{1}$
}

\author{
Márcio Dias Pereira ${ }^{2 *}$, Denise Cunha Fernandes dos Santos Dias 3 , Eduardo Euclydes \\ de Lima e Borges ${ }^{4}$, Sebastião Martins Filho ${ }^{5}$, Luiz Antônio dos Santos Dias ${ }^{3}$, \\ Paulo Emídio Soriano ${ }^{3}$
}

\begin{abstract}
The physic nut has been considered as one of the oilseed plants species with the highest potential for biofuel production. Oleaginous seeds demand special care during storage to maintain their quality. This study aimed to establish the most adequate conditions for their storage. Freshly-harvested seeds were dried until 7.2 moisture content and stored along a year, under the following conditions: environmental laboratory and cold chamber $\left( \pm 5^{\circ} \mathrm{C}\right.$ and $\left.60 \% \mathrm{RH}\right)$, into paper bag, polypropylene bag, and cardboard barrel. Physiological quality was then assessed by the tests: germination; first count; germination speed index; seedling length; accelerated aging; cold test; field emergence; and emergence speed index, after zero, three, six, nine, and 12 months. There was linear reduction of germination and vigor of the seeds after storage under environmental laboratory condition, into paper or polypropylene bags, and cardboard barrel. Physiological quality was higher after storage in cold chamber, into paper or polypropylene bags; and into cardboard barrel, at environmental laboratory condition.
\end{abstract}

Index terms: germination, vigor, seed deterioration.

\section{Qualidade fisiológica de sementes de pinhão manso (Jatropha curcas L.) durante o armazenamento}

\begin{abstract}
RESUMO - O pinhão manso vem se destacando como uma das espécies de plantas oleaginosas de maior aptidão para a produção de biodiesel. Sementes ricas em óleo demandam maior cuidado para a sua preservação durante o armazenamento. O objetivo deste trabalho foi estabelecer as condições mais adequadas para o armazenamento das sementes de pinhão manso. Sementes recém-colhidas foram secas até o teor de umidade de 7,2\% e armazenadas, ao longo de um ano, nas seguintes condições: ambiente de laboratório e câmara fria $\left( \pm 5^{\circ} \mathrm{C}\right.$ e $\left.60 \% \mathrm{UR}\right)$, em sacos de papel kraft, polipropileno trançado e em tambor de papelão.A qualidade fisiológica foi então avaliada pelos testes de: germinação; primeira contagem; índice de velocidade de germinação; comprimento de plântula; envelhecimento acelerado; teste de frio; emergência; e índice de velocidade de emergência, após zero, três, seis, nove e 12 meses. Houve redução linear da germinação e do vigor das sementes após armazenamento em ambiente natural, em saco de papel kraft, polipropileno trançado e tambor de papelão. A qualidade fisiológica das sementes foi maior após armazenamento em câmara fria, em embalagens de papel Kraft, polipropileno trançado; e tambor de papelão, em ambiente de laboratório.
\end{abstract}

Termos para indexação: germinação, vigor, deterioração de sementes.

\section{Introduction}

Seeds of oleaginous plants are of difficult preservation during storage once are very prone to deterioration. Generally, the intensity and speed of the deteriorative process is linked to chemical composition of the seeds. According to Freitas et al. (2009), cotton seeds present a strong trend to deterioration

${ }^{1}$ Submitted on 11/08/2011. Accepted for publication on 05/10/2012.

${ }^{2}$ Departamento de Agropecuária, Universidade Federal do Rio Grande do Norte, 59090-430-Natal, RN, Brasil.

${ }^{3}$ Departamento de Fitotecnia, Universidade Federal de Viçosa, 36570-000-Viçosa, MG, Brasil. because of their high oil content, demanding special attention and care during storage for the maintenance of their viability and vigor. Such aspect can be also considered valid for seed of physic nut (Jatropha curcas L.), which belongs to the Family Euphorbiaceae and has stood nationwide for its potential for production of biodiesel, due to the high oil content in the seeds; which can reach circa 40\% (Arruda, 2004).

${ }^{4}$ Departamento de Engenharia Florestal, Universidade Federal de Viçosa, 36570-000-Viçosa, MG, Brasil.

${ }^{5}$ Departamento de Estatística, Universidade Federal de Viçosa, 36570-000-Viçosa, MG, Brasil.

*Corresponding author < marcioagron@yahoo.com.br> 
Oleaginous seeds, such as those of physic nut, have difficult preservation in relation to other starchy seeds, once lipids are chemically less stable molecules than the starch. The peroxidation of lipids is frequently reported as one of the main causes of deterioration of seeds (McDonald Jr., 1999), which is a progressive process involving a sequence of events such as: changes on the membranes system; biosynthesis activity; reduction on germination speed; and potential of storage of the seeds (Delouche and Baskin, 1973). Despite impossible of being prevented, the deterioration process can be controlled by the storage under adequate conditions. Therefore, the knowledge of the behavior of seeds during storage is important in trying to increase their longevity, thus retarding their deterioration and avoiding significant losses in their physiological quality.

According to Joker and Jepsen (2003), the seeds of physic nut stored under natural environmental conditions, without control of temperature and relative humidity, are able to maintain their viability during one year. Ratree (2004) verified that germination of physic nut seeds decreased from $90 \%$ to $43 \%$ after 112 days of storage under environmental conditions. For Guzman and Aquino (2009), the storage temperatures of $20{ }^{\circ} \mathrm{C}$ and $0{ }^{\circ} \mathrm{C}$ were not determinants for maintaining the physiological quality of seeds along the storage period, but that their moisture content was the factor that most influenced reduction of germination and vigor. For these same authors, physic nut seeds, with moisture content between $4 \%$ and 5\% stored into impermeable packages, can be stored during one year with little reduction on germination percentage. They have also found that the moisture content of $9.5 \%$ was detrimental to seed quality. Moisture content between $7.9 \%$ and $8.4 \%$ was considered secure for storage of physic nut seeds under normal environmental conditions (Worang et al., 2008). These same authors have found that seeds placed into plastic packages and stored under laboratory normal environmental conditions have had reduction of germination from $89 \%$ to $75 \%$ after a month of storage; decreasing until $53 \%$ at the sixth month.

The information on the most adequate conditions for storage of physic nut seeds are still scarce, specially for the tropical Brazilian climatic conditions. In this sense, this study was aimed to assess the physiological quality of physic nut seeds stored in three different packages under two distinct environmental conditions, along 12 months.

\section{Material and Methods}

Freshly-harvested seeds of physic nut, collected in municipality of Janaúba, north of the State of Minas Gerais, Brazil, were dried naturally until reaching moisture content of approximately $7.2 \%$. These seeds were treated with the fungicide Captan 50 (135 g.100 seeds $\left.{ }^{-1}\right)$ and then packaged into three different types of packages: kraft paper bags, polypropylene bags, and cardboard barrels, with $4 \mathrm{~kg}$ of seed into each container. The paper bagsand braided polypropylene were closed with two folds at the upper edge and then holding them with staples. The cardboard barrels were covered with their lids during storage.

The seeds were stored under the following environmental conditions: environmental laboratory, in the Seed Research Laboratory at Federal University of Viçosa (at $\pm 25^{\circ} \mathrm{C}$ and $\pm 76 \%$ $\mathrm{RH}$ ); and controlled cold chamber (at $\pm 5^{\circ} \mathrm{C}$ and $60 \% \mathrm{RH}$ ), during 12 months; from January 2009 until February 2010. Six storage environmental conditions were assessed: environmental laboratory, into kraft paper bags, into braided polypropylene bags, into cardboard barrel; and cold chamber into kraft paper bags, into cold chamber, into braided polypropylene bags, into cardboard barrel.

Initially and at each three months $(0,3,6,9$, and 12 months) the seeds were assessed to determine moisture content and physiological quality (germination and vigor),whose tests and determinations are following described:

Moisture content: was performed by the oven method, at $105 \pm 3{ }^{\circ} \mathrm{C}$, for $24 \mathrm{~h}$, using three subsamples of 20 seeds each, for each replication; and results were expressed in percentage (Brasil, 2009).

Standard germination: was performed with four replications of 50 seeds each and eight subsamples of 25 seeds each, for each treatment. The seeds were uniformly distributed onto two sheets of germitest ${ }^{\mathbb{}}$ paper, covered with another sheet of the same paper, making rolls maintained into a germinator, at $30^{\circ} \mathrm{C}$. The sheets were moistened with distilled water, in a volume equivalent to 3.0 times the mass of dry substrate. The evaluation of normal seedlings was performed 10 days after seeding (Martins et al., 2008). Results were expressed as percentage of normal seedlings.

First count of germination: was carried out jointly with the germination test by counting the normal seedlings emerged at five days. Results were expressed as percentage of normal seedlings.

Germination speed index (GSI): was calculated according to equation proposed by Maguire (1962) with the daily germination values obtained in the standard germination test.

Seedling length: four replications of 20 seeds each (eight subsamples of 10 seeds each) were distributed on a line drawn at the upper third of the moistened germites $\mathrm{t}^{\circledR}$ paper (Krzyzanowski et al., 1999). Assessment of seedling length was performed, with the aid of a ruler graduated in centimeters, after 10 days after seeding. This test was carried out at the same conditions of the germination test; the results 
were expressed in $\mathrm{cm}$.seedling ${ }^{-1}$.

Cold test without soil: was conducted according to the same methodology described for the germination test, but the rolls remained for seven days in an incubator at $10^{\circ} \mathrm{C}$ (Krzyzanowski et al., 1999) and three days at $30^{\circ} \mathrm{C}$ in a germinator, when the counting of normal seedlings was performed. Results were expressed in percentage of the normal seedlings.

Seedling emergence: 200 seeds with four replications of 50 seeds each were used. The seeds of each replication were sowed into trays containing $4 \mathrm{~L}$ of a mixture of soil + sand (1:1), at approximately $1 \mathrm{~cm}$ deep. The trays were then maintained under laboratory environmental conditions until seedlings emergence. Results were expressed in percentage of normal seedlings emerged at $25^{\text {th }}$ days after sowing.

A completely randomized experimental design was used, with four replications and the treatments arranged into a $2 \mathrm{x}$ $3 \times 5$ factorial scheme 2 storage conditions (environmental laboratory and cold chamber) x 3 types of packages (kraft paper bags, braided polypropylene bags, and cardboard barrel) x 5 storage periods (0, 3, 6, 9, and 12 months)]. Data were subjected to ANOVA (SAS, 2009). Quantitative data were also subjected to regression analysis and qualitative data were compared by Tukey test, at $1 \%$ probability.

\section{Results and Discussion}

At packaging moment for storage, the physic nut seeds had a moisture content of $7.2 \%$, and after three months of storage there have been an increase in the moisture content of the seeds, in all treatments; which varied between $8.8 \%$ and $9.6 \%$ (Table 1).

Table 1. Moisture content of physic nut seeds stored during 12 months under two different environmental conditions and three different type of package.

\begin{tabular}{|c|c|c|c|c|c|c|c|}
\hline \multirow{3}{*}{ Storage conditions } & \multicolumn{7}{|c|}{ Moisture content (\%) } \\
\hline & \multicolumn{5}{|c|}{ Storage time (months) } & \multicolumn{2}{|c|}{ Regression } \\
\hline & 0 & 3 & 6 & 9 & 12 & Equations & $\mathrm{R}^{2}$ \\
\hline Environmental + paper bag & 7.21 & $9.57 \mathrm{a}^{*}$ & $9.61 \mathrm{a}^{*}$ & $9.44 a^{*}$ & $8.52 c^{*}$ & $\hat{Y}=8.37+0.08 x$ & 0.7 \\
\hline Environmental + polypropylene bag & 7.21 & $9.44 \mathrm{a}$ & $8.61 \mathrm{~b}$ & $9.05 \mathrm{a}$ & $9.61 b c$ & $\hat{\mathrm{Y}}=8.10+0.07 \mathrm{x}$ & 0.8 \\
\hline Environmental + cardboard barrel & 7.21 & $9.12 \mathrm{ab}$ & $9.39 \mathrm{a}$ & $9.12 \mathrm{a}$ & $9.29 \mathrm{a}$ & $\hat{Y}=8.10+0.07 x$ & 0.9 \\
\hline Cold chamber + paper bag & 7.21 & $8.81 \mathrm{~b}$ & $8.72 b$ & $8.95 \mathrm{a}$ & $9.2 \mathrm{ab}$ & $\hat{Y}=7.75+0.13 x$ & 0.9 \\
\hline Cold chamber + polypropylene bag & 7.21 & $9.2 \mathrm{ab}$ & $9.12 \mathrm{ab}$ & $9.37 \mathrm{a}$ & $9.43 \mathrm{a}$ & $\hat{Y}=7.98+0.19 x$ & 0.9 \\
\hline Cold chamber + cardboard barrel & 7.21 & $8.81 \mathrm{~b}$ & $9.01 \mathrm{ab}$ & $8.25 b$ & $8.42 \mathrm{c}$ & $\hat{\mathrm{Y}}=8.10+0,04 \mathrm{x}$ & 0.7 \\
\hline
\end{tabular}

*Means followed by the same letter in the column do not statistically by the Tukey test, at $1 \%$ probability.

From three months on, it was observed that the moisture content of the seeds have remained practically stable until 12 months of storage, with only slight oscillations; although for each storage period assessed, statistically significant differences among treatments have been observed. For Almeida et al. (2002), the moisture content of seeds is closely related to their preservation during storage, once it interferes in their chemical composition as well as in their metabolic activity. The seed moisture contained directly influences their quality; which according to Guzman and Aquino (2009), should not surpass $5 \%$ for seeds of physic nut.

Physic nut seeds stored under cold chamber environment have presented germination between $86 \%$ and $81 \%$, along 12 months of storage, when packaged into paper bags and into polypropylene bags (Table 2). For seeds stored into cardboard barrel under cold chamber conditions, however, the germination of the seeds decreased from $86 \%$, before storage, to $54 \%$ at the end of the storage period (12 months). The storage under natural environment has reduced seed germination to $52 \%$, when the packaging was carried out into paper bags and to $46 \%$, when the packaging was carried out into braided polypropylene bags. It can also be observed that when the seeds were packaged into cardboard barrel and stored under laboratory normal environment, their germination was more stable along the storage period (Table 2). Such results corroborate those findings of Ratree (2004) and Guzman and Aquino (2009), who have assessed the physiological quality of physic nut seeds stored during one year and have found that the environmental conditions have slowly reduced germination along that period.

In this study, it was observed statistically significant differences among treatments during all periods assessed indicating that the conditions in which the seeds were stored directly influence seed quality during storage. Nevertheless, generally from nine months on (Table 2) it was possible to detect, in a more evident manner, that the differences among treatments presenting the best seed germination were those in which the packaging 
was carried out into paper or polypropylene bags, when these containers were maintained under cold chamber controlled environment. However, for those seeds that have been packaged and stored into cardboard barrel, under environmental laboratory condition, the germination was higher than in the remaining treatments.

Table 2. Germination of physic nut seeds stored during 12 months under two different environmental conditions and three different type of package.

\begin{tabular}{|c|c|c|c|c|c|c|c|}
\hline \multirow{3}{*}{ Storage conditions } & \multicolumn{7}{|c|}{ Germination $(\%)$} \\
\hline & \multicolumn{5}{|c|}{ Storage time (months) } & \multicolumn{2}{|l|}{ Regression } \\
\hline & 0 & 3 & 6 & 9 & 12 & Equations & $\mathrm{R}^{2}$ \\
\hline Environmental + paper bag & 86 & $80 b^{*}$ & $76 b^{*}$ & $61 b^{*}$ & $52 b^{*}$ & $\hat{\mathrm{Y}}=88.35-2.88 \mathrm{x}$ & 0.9 \\
\hline Environmental + polypropylene bag & 86 & $84 a b$ & $78 \mathrm{ab}$ & $60 \mathrm{~b}$ & $46 c$ & $\hat{\mathrm{Y}}=91.6-3.47 \mathrm{x}$ & 0.9 \\
\hline Environmental + cardboard barrel & 86 & $83 \mathrm{ab}$ & $80 \mathrm{ab}$ & $80 \mathrm{a}$ & $78 \mathrm{a}$ & $\hat{\mathrm{Y}}=85.2-0.63 \mathrm{x}$ & 0.9 \\
\hline Cold chamber + paper bag & 86 & $86 \mathrm{a}$ & $82 \mathrm{a}$ & $81 \mathrm{a}$ & $81 \mathrm{a}$ & $\hat{\mathrm{Y}}=86.1-0.48 \mathrm{x}$ & 0.8 \\
\hline Cold chamber + polypropylene bag & 86 & $82 \mathrm{ab}$ & $82 \mathrm{a}$ & $82 \mathrm{a}$ & $81 \mathrm{a}$ & $\hat{\mathrm{Y}}=84.56-0.34 \mathrm{x}$ & 0.9 \\
\hline Cold chamber + cardboard barrel & 86 & $80 \mathrm{~b}$ & $70 \mathrm{c}$ & $88 b$ & $54 b$ & $\hat{\mathrm{Y}}=87.29-2.92 \mathrm{x}$ & 0.9 \\
\hline
\end{tabular}

*Means followed by the same letter in the column do not statistically differ between each other by the Tukey test, at $1 \%$ probability.

Even under low temperature conditions, seeds with high oil content may have their germination reduced along the storage and may completely lose their germination capacity after one year (Nazreen et al., 2000). Guzman and Aquino (2009), after storing seeds of physic nut during 12 months, at temperature of $0{ }^{\circ} \mathrm{C}$, have observed that germination dropped from $96 \%$ to $55 \%$ during that period; under natural environment conditions, however, after 12 months storage, the seeds have also lost their germination capacity. For Carneiro and Aguiar (1993), the combination of impermeable packaging and high temperatures can be prejudicial to physiological quality of stored seeds. According to Worang et al. (2008), such combination may accelerate the respiratory process and cause degradation of lipids, increasing activity of enzymes and the accumulation of fatty acids in the seed cells; thus reducing their germination capacity.

The reduction on vigor of seeds during storage can be noticed through the smaller number of normal seedlings in the first count of germination test (Table3). Initially, germination was $74 \%$ in all treatments. After 12 months storage, it was observed a more accentuated reduction of germination for the seeds stored under natural environment, into paper bags (13\%) and polypropylene bags (12\%). After three months storage, it was already observed lower performance for seeds stored under laboratory environmental, into polypropylene and paper bags, or for seeds stored under cold chamber, packaged into barrel of cardboard. Such behavior was maintained until 12 months of storage. The highest vigor was observed for seeds stored under cold chamber condition, into packaging of kraft paper bag, during all storage period.

For Worang et al. (2008), physic nut seeds stored along six months have had their germination reduced when stored under natural environment into plastic containers. According to Guzman and Aquino (2009), however, when seeds of this species were subjected to storage under low temperature conditions, the germination was maintained practically on circa $90 \%$ along 12 months. These results corroborate results observed in this study, therefore demonstrating the effect of the temperature of environment storage on the maintenance of the seed quality.

The GSI has been reduced during the storage period for all packaging and environmental conditions studied (Table 4). Hence confirming the drop on vigor of seeds during that period.

Initially, the GSI for the physic nut seeds was 17.2, for all treatments. However, similar to what happened for the first count of germination, there was also a decrease in the GSI, i.e., on vigor of seeds, for all treatments assessed; with differences statistically significant among results of each treatment and for each time of assessment (Table 4). In general, seeds packed into cardboard barrel and stored under natural environment conditions, have maintained their high vigor throughout the storage period. The lowest vigor has been found for the seeds stored into cardboard barrel, under cold chamber environment; or then for seeds into packaging of kraft paper or packaging of braided polypropylene and stored under laboratory environmental condition. According to Saturnino (2005), seeds of oilseed plants, such as physic nut, have natural reduction of their longevity during the storage process, and for this reason, should be kept into porous packaging, when stored under natural environment conditions, in order to avoid sharp loss of vigor. Nevertheless, in the present study it was observed better performance for seeds kept into the least porous of the containers used (cardboard barrel) and stored under laboratory environmental conditions. 
Table 3. First count of germination of physic nut seeds stored during 12 months under two different environmental conditions and three different type of package.

\begin{tabular}{|c|c|c|c|c|c|c|c|}
\hline \multirow{3}{*}{ Storage conditions } & \multicolumn{7}{|c|}{ First count of germination $(\%)$} \\
\hline & \multicolumn{5}{|c|}{ Storage time (months) } & \multicolumn{2}{|c|}{ Regression } \\
\hline & 0 & 3 & 6 & 9 & 12 & Equations & $\mathrm{R}^{2}$ \\
\hline Environmental + paper bag & 74 & $60 \mathrm{~cd} *$ & $53 \mathrm{~cd}^{*}$ & $32 \mathrm{de}^{*}$ & $13 d^{*}$ & $\hat{\mathrm{Y}}=76.50-5.01 \mathrm{x}$ & 0.9 \\
\hline Environmental + polypropylene bag & 74 & $56 \mathrm{~d}$ & $48 \mathrm{~d}$ & $27 \mathrm{e}$ & $12 d$ & $\hat{\mathrm{Y}}=73.95-5.11 \mathrm{x}$ & 0.9 \\
\hline Environmental + cardboard barrel & 74 & $64 \mathrm{abc}$ & $56 \mathrm{bc}$ & $48 \mathrm{c}$ & $45 b$ & $\hat{\mathrm{Y}}=72.35-2.52 \mathrm{x}$ & 0.9 \\
\hline Cold chamber + paper bag & 74 & $68 \mathrm{a}$ & $65 \mathrm{a}$ & $60 \mathrm{a}$ & $57 \mathrm{a}$ & $\hat{\mathrm{Y}}=73.15-1.40 \mathrm{x}$ & 0.9 \\
\hline Cold chamber + polypropylene bag & 74 & $66 \mathrm{ab}$ & $60 \mathrm{ab}$ & $54 b$ & $47 b$ & $\hat{\mathrm{Y}}=73.21-2.17 \mathrm{x}$ & 0.8 \\
\hline Cold chamber + cardboard barrel & 74 & $62 \mathrm{bc}$ & $48 \mathrm{~d}$ & $34 d$ & $31 \mathrm{c}$ & $\hat{\mathrm{Y}}=72.70-3.81 \mathrm{x}$ & 0.9 \\
\hline
\end{tabular}

*Means followed by the same letter in the column do not statistically differ by the Tukey test, at $1 \%$ probability.

Table 4. Germination speed index (GSI) of physic nut seeds stored during 12 months under two different environmental conditions and three different type of package.

\begin{tabular}{|c|c|c|c|c|c|c|c|}
\hline \multirow{3}{*}{ Storage conditions } & \multicolumn{7}{|c|}{ GSI } \\
\hline & \multicolumn{5}{|c|}{ Storage time (months) } & \multicolumn{2}{|c|}{ Regression } \\
\hline & 0 & 3 & 6 & 9 & 12 & Equations & $\mathrm{R}^{2}$ \\
\hline Environmental + paper bag & 17.2 & $15.2 \mathrm{~d}^{*}$ & $14.4 d^{*}$ & $13.6 \mathrm{e}^{*}$ & $10.5 d^{*}$ & $\hat{Y}=17.22-2.05 x$ & 0,9 \\
\hline Environmental + polypropylene bag & 17.2 & $15.8 \mathrm{~d}$ & $15.1 \mathrm{c}$ & $14.6 \mathrm{~d}$ & $11.7 \mathrm{c}$ & $\hat{\mathrm{Y}}=17.14-0.41 \mathrm{x}$ & 0.9 \\
\hline Environmental + cardboard barrel & 17.2 & $17.4 \mathrm{a}$ & $17.5 \mathrm{a}$ & $17.2 \mathrm{a}$ & $16.3 \mathrm{a}$ & $\hat{\mathrm{Y}}=17.57-0.06 \mathrm{x}$ & 0,8 \\
\hline Cold chamber + paper bag & 17.2 & $16.5 b$ & $16.0 \mathrm{~b}$ & $15.8 \mathrm{~b}$ & $14.6 b$ & $\hat{\mathrm{Y}}=17.25-0.25 \mathrm{x}$ & 0.9 \\
\hline Cold chamber + polypropylene bag & 17.2 & $15.6 \mathrm{c}$ & $15.4 \mathrm{c}$ & $15.1 \mathrm{c}$ & $14.4 \mathrm{~b}$ & $\hat{\mathrm{Y}}=16.87-0.21 \mathrm{x}$ & 0,7 \\
\hline Cold chamber + cardboard barrel & 17.2 & $14.5 \mathrm{e}$ & $14.3 \mathrm{~d}$ & $13.3 \mathrm{e}$ & $10.7 \mathrm{~d}$ & $\hat{\mathrm{Y}}=16.84-0.46 \mathrm{x}$ & 0.5 \\
\hline
\end{tabular}

* Means followed by the same letter in the column do not statistically differ by the Tukey test, at $1 \%$ probability.

Table 5 shows that before beginning the storage (month 0 ), seedling length mean of $17.4 \mathrm{~cm}$; and this was the highest value found for this variable in the experiment. Along the 12 months storage, it was verified that a reduction on size of seedlings occurred in all treatments, also indicating reduction on vigor of the seeds. At the third month, higher values for seedling length were obtained with the seeds assessed after storage into paper bags and braided polypropylene bags, under both environmental conditions studied. After six and nine months of storage, however, better performance was observed for the seeds stored into cold chamber and packaged into braided polypropylene bags; mainly in relation to seeds that were kept into cardboard barrel under the same environment. At the end of the storage period (12 months) it was observed that the largest seedlings were obtained in the treatment with storage under environmental laboratory, into cardboard barrel; while the smallest length of seedlings were found in the treatments: environmental laboartory, into paper bags and cold chamber into cardboard barrel (Table 5). Souza et al. (2005) have also observed reduction on length of seedlings of Tabebuia serratifolia Vahl Nich. stored under natural environment and cold chamber environment along the storage period.

On Table 6 are shown the results on vigor of physic nut seeds assessed by the cold test without soil. The seeds behavior was similar to what was observed in the other vigor tests (first count of germination, germination speed index, and length of seedlings) in relation to the remaining treatments (Tables 3, 4, and 5, respectively). Assessing separately each storage period (Table 6), it can be observed that the seed maintained into cold chamber, independent of packaging, presented better preservation along the storage period; and that the packaging into cardboard barrel was not adequate for maintenance of seed quality under cold temperature (cold chamber environment) and did not statistically differed from the natural environment condition, when the seeds were stored into kraft paper bag or of braided polypropylene bag.

It has to be emphasized, however, that under natural environment condition, the seeds presented good results for vigor when stored into cardboard barrel. For Copeland and McDonald (2001), seeds with high content of lipids tend to undergo natural reduction on their vigor along the storage, even under conditions considered favorable; and far higher 
than the loss of vigor of seeds with high starch content; although the germination still remains close to values presented before storage.

Through data presented on Table 7, it can be verified that the emergence of physic nut seedlings, grown from seeds packaged into paper bags and stored in the cold chamber was practically maintained at the same level along all storage period; with a more accentuated reduction for the treatments: environmental laboratory, into paper bags and polypropylene bags; and cold chamber into cardboard barrel, starting from three months of storage. Seeds stored under environmental laboratory into cardboard barrel presented emergence similar to the seeds stored in cold chamber, into paper and polypropylene bags; thus indicating that the cardboard barrel can be a feasible alternative for maintenance of vigor of physic nut seeds under natural environmental conditions for a longer period.

Table 5. Seedling length from physic nut seeds stored during 12 months under two different environmental conditions and three different type of packaging.

\begin{tabular}{|c|c|c|c|c|c|c|c|}
\hline \multirow{3}{*}{ Storage conditions } & \multicolumn{7}{|c|}{ Seedling length $\left(\mathrm{cm}\right.$ seedling $\left.^{-1}\right)$} \\
\hline & \multicolumn{5}{|c|}{ Storage time (months) } & \multicolumn{2}{|c|}{ Regression } \\
\hline & 0 & 3 & 6 & 9 & 12 & Equations & $\mathrm{R}^{2}$ \\
\hline Environmental + paper bag & 17.4 & $17.2 \mathrm{a}^{*}$ & $14.4 c^{*}$ & $10.3 d^{*}$ & $7.5 c^{*}$ & $\hat{Y}=18.73-0.89 x$ & 0.9 \\
\hline Environmental + polypropylene bag & 17.4 & $17.2 \mathrm{a}$ & $15.3 b$ & $12.5 b$ & $9.1 \mathrm{~b}$ & $\hat{\mathrm{Y}}=18,62-0,71 \mathrm{x}$ & 0,9 \\
\hline Environmental + cardboard barrel & 17.4 & $15.5 b$ & $13.6 \mathrm{~d}$ & $11.6 \mathrm{c}$ & $10.6 \mathrm{a}$ & $\hat{\mathrm{Y}}=17.25-0.58 \mathrm{x}$ & 0.8 \\
\hline Cold chamber + paper bag & 17.4 & $17.4 \mathrm{a}$ & $15.4 \mathrm{~b}$ & $12.4 \mathrm{~b}$ & $9.5 \mathrm{~b}$ & $\hat{Y}=18.61-0.69 x$ & 0.9 \\
\hline Cold chamber + polypropylene bag & 17.4 & $17.4 \mathrm{a}$ & $16.3 \mathrm{a}$ & $13.6 \mathrm{a}$ & $9.4 \mathrm{~b}$ & $\hat{Y}=18.64-0.64 x$ & 0.8 \\
\hline Cold chamber + cardboard barrel & 17.4 & $15.7 \mathrm{~b}$ & 12.e & $10.4 \mathrm{~d}$ & $9.3 b$ & $\hat{\mathrm{Y}}=17.33-0.71 \mathrm{x}$ & 0.8 \\
\hline
\end{tabular}

*Means followed by the same letter in the column do not statistically differ by the Tukey test, at $1 \%$ probability.

Table 6. Germination by the cold test of physic nut seeds stored during 12 months under two different environmental conditions and three different type of packaging.

\begin{tabular}{|c|c|c|c|c|c|c|c|}
\hline \multirow{3}{*}{ Storage conditions } & \multicolumn{7}{|c|}{ Germination in the cold test $(\%)$} \\
\hline & \multicolumn{5}{|c|}{ Storage time (months) } & \multicolumn{2}{|c|}{ Regression } \\
\hline & 0 & 3 & 6 & 9 & 12 & Equations & $\mathrm{R}^{2}$ \\
\hline Environmental + paper bag & 64 & $46 c^{*}$ & $37 \mathrm{e}^{*}$ & $26 c^{*}$ & $21 \mathrm{~cd} *$ & $\hat{Y}=60.00-3.53 x$ & 0.9 \\
\hline Environmental + polypropylene bag & 64 & $43 c$ & $42 \mathrm{de}$ & $32 c$ & $23 c$ & $\hat{\mathrm{Y}}=59.40-3.41 \mathrm{x}$ & 0.9 \\
\hline Environmental + cardboard barrel & 64 & $56 \mathrm{ab}$ & $50 \mathrm{bc}$ & $46 b$ & $40 \mathrm{~b}$ & $\hat{Y}=62.80-1.93 x$ & 0.9 \\
\hline Cold chamber + paper bag & 64 & $62 \mathrm{a}$ & $58 \mathrm{a}$ & $54 \mathrm{a}$ & $48 \mathrm{a}$ & $\hat{\mathrm{Y}}=65.20-1.33 \mathrm{x}$ & 0.9 \\
\hline Cold chamber + polypropylene bag & 64 & $57 \mathrm{ab}$ & $55 \mathrm{ab}$ & $53 \mathrm{a}$ & $47 \mathrm{a}$ & $\hat{\mathrm{Y}}=62.69-1.25 \mathrm{x}$ & 0.8 \\
\hline Cold chamber + cardboard barrel & 64 & $55 \mathrm{~b}$ & $46 \mathrm{~cd}$ & $26 c$ & $15 \mathrm{~d}$ & $\hat{\mathrm{Y}}=67.31-4.32 \mathrm{x}$ & 0.8 \\
\hline
\end{tabular}

*Means followed by the same letter in the column do not statistically differ by the Tukey test, at $1 \%$ probability.

Table 7. Emergence of seedlings obtained of physic nut seeds stored during 12 months under two different environmental conditions and three different type of packaging.

\begin{tabular}{|c|c|c|c|c|c|c|c|}
\hline \multirow{3}{*}{ Storage conditions } & \multicolumn{7}{|c|}{ Emergence (\%) } \\
\hline & \multicolumn{5}{|c|}{ Storage time (months) } & \multicolumn{2}{|c|}{ Regression } \\
\hline & 0 & 3 & 6 & 9 & 12 & Equations & $\mathrm{R}^{2}$ \\
\hline Environmental + paper bag & 70 & $58 c^{*}$ & $44 c^{*}$ & $32 d^{*}$ & $26 d^{*}$ & $\hat{\mathrm{Y}}=68.8-3.80 \mathrm{x}$ & 0.9 \\
\hline Environmental + polypropylene bag & 70 & $62 \mathrm{bc}$ & $56 \mathrm{~b}$ & $48 \mathrm{c}$ & $34 \mathrm{c}$ & $\hat{\mathrm{Y}}=71.2-2.86 \mathrm{x}$ & 0.9 \\
\hline Environmental + cardboard barrel & 70 & $66 a b$ & $60 \mathrm{~b}$ & $57 \mathrm{~b}$ & $44 \mathrm{~b}$ & $\hat{Y}=71.6-2.03 x$ & 0.9 \\
\hline Cold chamber + paper bag & 70 & $70 \mathrm{a}$ & $68 \mathrm{a}$ & $68 \mathrm{a}$ & $68 \mathrm{a}$ & $\hat{\mathrm{Y}}=70.23-1.33 \mathrm{x}$ & 0.9 \\
\hline Cold chamber + polypropylene bag & 70 & 64abc & $58 \mathrm{~b}$ & $52 \mathrm{bc}$ & $49 b$ & $\hat{\mathrm{Y}}=68.48-1.81 \mathrm{x}$ & 0.7 \\
\hline Cold chamber + cardboard barrel & 70 & $60 \mathrm{bc}$ & $54 \mathrm{~b}$ & $46 c$ & $33 \mathrm{c}$ & $\hat{\mathrm{Y}}=70.23-2.94 \mathrm{x}$ & 0.8 \\
\hline
\end{tabular}

*Means followed by the same letter in the column do not statistically differ between each other by the Tukey test, at $1 \%$ probability 
Results reported by Paula et al. (1997) with Hevea brasiliensis Müll. Arg. Seeds showed that storage under low temperature was more efficient in maintaining viability of seeds than normal environmental temperature. For castor bean (Ricinus communis L.) seeds stored into kraft paper, under natural environment conditions during one year, Fanan et al. (2009) did not found large variations for the emergence of seedlings of this species along the storage period.

\section{Conclusions}

There is a natural reduction on germination and vigor of physic nut seeds during storage, independent of environmental conditions and of the kind of package.

The more adequate conditions for storage of physic nut seeds are storage into kraft paper or braided polypropylene bag, in a cold chamber or packaging into barrel of cardboard, with storage under environmental laboratory condition.

\section{References}

ALMEIDA, F.A.C.; MORAIS, A.M.; CARVALHO, J.M.F.C.; GOUVEIA, J.P.G. Crioconservação de sementes de mamona das variedades nordestina e pernambucana. Revista Brasileira de Engenharia Agrícola e Ambiental, v.6, n.2, p.295-302, 2002. http://www.scielo.br/scielo.php?script=sci_pdf\&pid=s $141543662002000200019 \& \operatorname{lng}=$ en\&nrm=iso\&tlng=pt

ARRUDA, F.P. Cultivo de pinhão-manso (Jatropha curcas L.) como alternativa para o semi-árido nordestino. Revista Brasileira Oleaginosas e Fibrosas, v.8, n.1, p.789-799, 2004. http://www.cnpa.embrapa.br/rbof/ fasciculos.php

BRASIL. Ministério da Agricultura, Pecuária e Abastecimento. Regras para análise de sementes. Ministério da Agricultura, Pecuária e Abastecimento. Secretaria de Defesa Agropecuária. Brasília: MAPA/ACS, 2009. 395p. http://www.agricultura.gov.br/arq_editor/file/laborat $\%$ c3\%b3rio/sementes/ regras $\% 20$ para $\% 20$ analise $\% 20 \mathrm{de} \% 20$ sementes.pdf

CARNEIRO, J.G.A.; AGUIAR, I.B. Armazenamento de sementes. In: AGUIAR, I.B.; PIÑA-RODRIGUES, F.C.M.; FIGLIOLIA, M.B. (Coord.) Sementes florestais tropicais. Brasília: ABRATES, 1993. p.333-350.

COPELAND, L.O.; McDONALD, M.B. Principles of seed science and technology. 4th ed. Boston: Kluwer Academic Publishers, 2001. 430p.

DELOUCHE, J.C.; BASKIN, C.C. Accelerated aging techniques for predicting the relative storability of seed lots. Seed Science and Technology, v.1, p.427-452, 1973.

FANAN, S.; MEDINA, P.F.; CAMARGO, M.B.P.; RAMOS, N.P. Influência da colheita e do armazenamento na qualidade fisiológica de sementes de mamona. Revista Brasileira de Sementes, v.31, n.1, p.150-159, 2009. http:// www.scielo.br/scielo.php?script=sci_arttext\&pid=S0101312220090001000 $17 \& \operatorname{lng}=$ pt\&nrm=iso\&tlng $=$ pt

FREITAS, R.A.; DIAS, D.C.F.S; OLIVEIRA, M.G.A.; DIAS， L.A.S.; HILST, P.C. Physiological and biochemical changes in cotton seeds during storage. Revista Brasileira de Armazenamento, v.34, n.1, p.64-69, 2009.

GUZMAN, L.E.P; AQUINO, A.L. Seed characteristics and storage behavior of physic nut (Jatropha curcas L.). Philippine Journal of Crop Science (PJCS), v.34, n.1, p.13-21, 2009.

JOKER, D.; JEPSEN, J. Jatropha curcas L. Seed Leaflet, n.83, p.1-2, 2003.

KRZYZANOWSKI, F.C.; VIEIRA, R.D; FRANÇA-NETO, J.B. (Ed.) Vigor de sementes: conceitos e testes. Londrina: ABRATES, 1999. p.6.1-6.8

MAGUIRE, J.D. Speed of germination-aid in selection and evaluation for seedling emergence and vigor. Crop Science, v.2, n.1, p.176-177, 1962.

MARTINS, C.C.; MACHADO, C.G.; CAVASINI, R. Temperatura e substrato para o teste de germinação de sementes de pinhão-manso. Revista Ciência e Agrotecnologia, v.32, n.3, p. 863-868. 2008. http://www.editora.ufla.br/site/_ adm/upload/revista/32-3-2008_24.pdf

McDONALD JR.; M.B. Seed deterioration: physiology, repair and assessment. Seed Science and Technology, v.27, p.177-237, 1999.

NAZREEN, .S.; KHAN, B.R.; MOHMAND, A.S. The effect of storage temperature, storage period and seed moisture content on seed viability of soybean. Pakistan Journal of Biological Sciences, v.3, n.12, p.2003-2004, 2000.

PAULA, N.F.; BORGES, E.E.L.; BORGES, R.C.G.; PAULA, R.C. Alterações fisiológicas em sementes de seringueira (Hevea brasiliensis Muell.Arg.) durante o armazenamento. Revista Brasileira de Sementes, v.19, n.2, p.326-333, 1997. http://www.abrates.org.br/revista/artigos/1997/v19n2/ artigo29.pdf

RATREE, S.A. Preliminary study on physic nut (Jatropha curcas L.) in Thailand. Journal of Biological Sciences, v.7, n.9, p.1620-1623, 2004.

SAS. SAS Programming 9.3. Cary: SAS, 2009. Software.

SATURNINO, H.M. Cultura do pinhão-manso. Informe Agropecuário, v.26, n.229, p.44-78, 2005.

SOUZA, V.C.; BRUNO, R.L.A.; ANDRADE, L.A. Vigor de sementes armazenadas de ipê amarelo Tabebuia serratifolia (Vahl.) Nich. Revista Árvore, v.29, n.6, p.833-841, 2005. http://www.scielo.br/scielo. php?script=sci_arttext\&pid=S0100-67622005000600001

WORANG, R.L.; DHARMAPUTRA, O.S.; SYARIEF, R.; MIFTAHUDIN, S. The quality of physic nut (Jatropha curcas L.) seeds packed in plastic material during storage. Biotropica, v.15, n.1, p.25-36, 2008. http://journal.biotrop.org/ index.php/biotropia/article/view/3/5 